\title{
Cryptomeria japonica D. Don trees shoot biomass partitioning in a stand located in southeastern Paraná
}

\author{
Partição da biomassa aérea de árvores de Cryptomeria japonica D. Don \\ em um povoamento localizado no sudeste do Paraná
}

\section{Carlos Roberto SANQUETTA ${ }^{1}$; Mateus Niroh Inoue SANQUETTA²; Francelo MOGNON³; Ana Paula Dalla CORTE ${ }^{4}$; Aurélio Lourenço RODRIGUES ${ }^{5}$}

\begin{abstract}
${ }^{1} \mathrm{PhD}$ em Engenharia Florestal. Universidade Federal do Paraná E-mail: carlos sanquetta@hotmail.com
${ }^{2}$ Graduando em Engenharia Florestal. Universidade Federal do Paraná. E-mail: mateus.sanquetta@hotmail.com

${ }^{3}$ Doutorando em Engenharia Florestal. Universidade Federal do Paraná. E-mail: mognonf@gmail.com

${ }^{4}$ Autor para correspondência. Doutor em Engenharia Florestal. Universidade Federal do Paraná - UFPR, Departamento de Ciências Florestais - DECIF, Av. Pref. Lothário Meissner, 900 - Jardim Botânico - Campus III - 80210-170 - Curitiba - Paraná - Brasil. E-mail: anapaulacorte@gmail.com

${ }^{5}$ Doutorando em Engenharia Florestal. Universidade Federal do Paraná. E-mail: alourencorodrigues@gmail.com
\end{abstract}

Recebido em: 05-09-2014; Aceito em: 17-04-2015

\begin{abstract}
The purpose of this study was to evaluate the partitioning of individual dry aboveground biomass in Cryptomeria japonica trees, as on its compartments as well as in the vertical profile, and examine whether the Pipe Model Theory, which states a rule between the plant organs, applies to the present case. Data were collected in a plantation established in 1984 in Rio Negro - PR. Twenty representative trees of the population distributed by diameter class were felled and weighed in the field, and their dry biomass were analyzed according to horizontal layers of $5 \mathrm{~m}$ wide in the following biomass compartments: sapwood, heartwood, bark, branches and foliage. Biomass is mostly composed by the stem (73.67\%). In the wood, $41.66 \%$ of the biomass corresponds to sapwood, $26.66 \%$ to heartwood and $5.35 \%$ to bark. The canopy accounts for $26.33 \%$ of the dry biomass, which is represented at $13.75 \%$ by branches and $12.58 \%$ by foliage. In the first five meters tree biomass is comprised exclusively of wood and bark. From $5 \mathrm{~m}$ crown begins to have participation in biomass, becoming the major fraction from $15 \mathrm{~m}$ and above in the vertical profile. The partitioning of biomass in heartwood decreases along the vertical profile of the tree, i.e., it is largest at the base and smaller in the lower stratum. This study indicates that the Pipe Model Theory applies to the Cryptomeria japonica forest stand.
\end{abstract}

Additional keywords: bole; crown; heartwood; japanese cedar; sapwood.

\section{Resumo}

Este estudo objetivou avaliar a partição da biomassa aérea seca em árvores de Cryptomeria japonica, tanto em compartimentos como no perfil vertical, e examinar se a Teoria do Modelo do Cano (Pipe Model Theory), que estabelece uma regra de proporção entre os órgãos da planta, aplica-se ao caso. Os dados foram coletados em um plantio estabelecido em 1984, no município de Rio Negro - PR. Vinte árvores representativas do povoamento distribuídas por classe diamétrica foram derrubadas e pesadas em campo, e suas biomassas secas foram analisadas segundo camadas horizontais de $5 \mathrm{~m}$ de amplitude, nos compartimentos: alburno, cerne, casca, galhos e folhas. A biomassa é constituída principalmente pelo fuste (73,67\%). No lenho, $41,66 \%$ da biomassa correspondem ao alburno, $26,66 \%$ ao cerne e 5,35\% à casca. A copa compreende $26,33 \%$ da biomassa aérea seca, sendo representada por $13,75 \%$ de galhos e $12,58 \%$ pelas folhas. Nos primeiros cinco metros da árvore, a biomassa é constituída exclusivamente de lenho e casca. A partir de $5 \mathrm{~m}$, a biomassa da copa começa a ter participação, vindo a ter maior fração a partir dos $15 \mathrm{~m}$ do perfil vertical do povoamento. A participação do cerne na biomassa decresce ao longo do perfil vertical das árvores, ou seja, é maior na base e menor nas porções mais altas. Este estudo indica que a Teoria do Modelo do Cano se aplica ao povoamento florestal de Cryptomeria japonica.

Palavras-chave adicionais: alburno; cedro-japonês; cerne; copa; fuste.

\section{Introduction}

Forest ecosystems represent about $80 \%$ of terrestrial biomass (Gardner \& Mankin, 1981; Kindermann et al., 2008). Biomass is a term used to express the plant or animal matter mass amount, dead or alive (Silveira et al., 2008). The forest biomass term can mean all the existing biomass in the forest or only its tree fraction (Sanquetta, 2002).

Biomass distribution or partition between several tree or forest components, such as foliage, stems, roots, etc., is important to determine its potential 
growth (leaves and fine roots), structural stability (stem and thick roots) and its products economic use (mainly the stem) (Landsberg \& Sands, 2011). The relative biomass amount in several organs, also called biomass allocation, varies among species, age (time) and sites (Poorter et al., 2012).

Biomass partitioning models have been proposed in order to understand the allometric relation between the different tree parts and populations. Shinozaki et al. (1964) proposed the so-called Pipe Model Theory to describe biomass vertical distribution along an individual tree vertical profile, which, according to authors, also works for stands. This theory has been used by several authors (Waring et al., 1982; Chiba, 1998; Jelonek et al., 2008; Dean et al., 2013) to explain plants form and function in general, particularly of trees. However, there are few practical studies on tree species biomass vertical distribution (Gillespie et al., 1994; Telenius \& Verwijst, 1995; Yen et al., 2013). In Brazil, this type of study is very recent, especially with conifer species.

Cryptomeria japonica, known as Japanese cedar, is a native of Japan's temperate region conifer and of part of China, where is one of the most commercially important species. In Brazil, it is planted on a small scale for decades, although having a recognized silviculture potential, particularly for high-quality timber production. In Brazil, the species has great growth in localities with temperatures between 12 and $14^{\circ} \mathrm{C}$, with average annual rainfall above $2.000 \mathrm{~mm}$ (Alves et al., 1984). Capaldi (2002) highlights the rapid growth, especially in the early years, when it can be similar to species of great importance in Brazilian forestry, such as Pinus taeda (Dobner Júnior et al., 2013).

This study aims to analyze biomass partition into compartments (stem, branches and leaves) and in Cryptomeria japonica D. Don adult subject vertical profile, established in pure planting. It also aims to test whether the Pipe Model Theory, proposed by Shinozaki et al. (1964), which is widely employed in plant species studies, applies to describe biomass vertical distribution along the individual tree vertical profile.

\section{Material and methods}

\section{Study area characterization}

This study was developed in a Cryptomeria japonica stand implanted between February and April 1980, in Rio Negro Experimental Station, which belongs to the Federal University of Paraná. The station is located along the BR-116 highway, whose office is located about $5 \mathrm{~km}$ from the city of Rio Negro, State of Paraná. Planting implementation took place with 1.667 trees/hectare and spacing of $3 \mathrm{~m} \times 2 \mathrm{~m}$, with no commercial thinning being carried out in the area until assessment time. Further silvicultural population details are found in Shimizu \& Maiochi (2007).

The region is located in the second Paraná plateau, in the southeast of the state, in latitude $26^{\circ} 06^{\prime}$
South and longitude $49^{\circ} 47^{\prime}$ West, with an average altitude of 780 meters. According to Köppen classification, the climate is characterized as $\mathrm{Cfb}$, with the warmest month mean temperature being below $22^{\circ} \mathrm{C}$ (Pereira, 2009). The historical rainfall for the study site is between 1.400 and $1.600 \mathrm{~mm}$ annually (Simepar, 2008 apud Pereira, 2009). The region soil was characterized by Shimizu \& Maiochi (2007) as low fertility red-yellow Podzolic, with high aluminum content, high acidity and low phosphorus content. Site soil analysis details are found in Carvalho (2011).

\section{Trees sampling and measurement}

For this study, twenty dbh values in the amplitude distribution range were randomly selected within the diameter classes observed in the stand. Subsequently, individuals who represented the selected dbhs were found, therefore being stand representative trees when planting was carried out 30 years ago. Trees were measured at diameter at breast height (dbh), i.e., $1.30 \mathrm{~m}$ from the soil surface, using a mechanical caliper. Each tree total height was directly measured with tape after its chop down, performed with chainsaw.

Subsequently, the biomass weighing technique of $5 \mathrm{~m}$ horizontal layers was applied, according to tree profile, what is called stratified clipping technique (Sanquetta, 2002). Stem, branches and foliage biomass were compartmentalized in horizontal sections corresponding to vertical positions relative to the total tree height and determined with digital $0.1 \mathrm{~kg}$ precision scale. Three representative discs of each tree were collected, which corresponded to trees base, middle and top. Leaves and branches samples were also collected and taken to the laboratory for analysis.

\section{Laboratory analysis and statistics}

Samples were dried in an oven at $70{ }^{\circ} \mathrm{C}$. Bark was removed from stem discs. The sapwood disk wood portion was also separated from that of the heartwood, with chisel and hammer, and magnifying glass observation. After drying, samples fresh biomass conversion to dry was performed for the studied compartments.

Biomass Expansion Factor (BEF) was calculated to the sampled trees, according to the methodology shown in Sanquetta et al. (2011).

$$
\mathrm{BEF}=\frac{\mathrm{P}_{\text {crown }}+\mathrm{P}_{\text {stem }}}{\mathrm{P}_{\text {stem }}}=\frac{\mathrm{P}_{\text {shoot }}}{\mathrm{P}_{\text {stem }}}
$$

Where:

BEF - Biomass expansion factor (dimensionless);

Pcrown - tree crown dry weight $(\mathrm{g})$;

Pstem - tree stem dry weight $(\mathrm{g})$;

Pshoot - tree stem dry weight + tree crown weight $(\mathrm{g})$.

Biomass data for heartwood and sapwood, bark, branches and foliage compartments were organized into 5 sections of equal amplitude in relation to trees total height: $<5 \mathrm{~m}, 5$ to $10 \mathrm{~m}, 10.1$ to $15 \mathrm{~m}, 15$ 
to $20 \mathrm{~m}, 20.1$ to $25 \mathrm{~m}$, greater than $25 \mathrm{~m}$.

Results were submitted to Kolmogorov-Smirnov's (D), Cramér-von Mises's (W2), AndersonDarling's (A2), Kuiper's (V), Watson's (U2), Lilliefors' (D) and Shapiro-Wilk's (W) normality tests, which were available on ASSISTAT software. Individual tree biomass variance homogeneity analysis per section was also carried out through Bartlett's test for a value of $\alpha=0.05$.

A regression equation was adjusted to estimate the individual dry above-soil biomass for twenty trees under study. The adjusted model was as follows:

$\ln (b)=\beta_{0}+\beta_{1} \ln (d b h)+\beta_{2} \ln (h t)$

Where:

b - dry above-soil biomass (kg);

$\mathrm{dbh}$ - diameter at breast height $(\mathrm{cm})$;

ht - total height $(\mathrm{m})$;

$\beta_{0}, \beta_{1}, \beta_{2}$ - ordinary linear regression adjusted coefficients.

Each model was defined in accordance with the adjusted determination coefficient ( $\left.R^{2} a j.\right)$ and estimate standard error in percentage (Syx\%) (Sanquetta et al., 2014). Based on individual estimates, the stand biomass stock was estimated.

Pipe Model Theory application was graphically assessed. According to Shinozaki et al. (1964), the theory is based on the relation between foliar biomass (C (z)) and other organs corresponding cumulative series $(F(z))$ in each $z$ horizontal layer along the tree vertical profile. $\mathrm{C}(\mathrm{z})$ and $\mathrm{F}(\mathrm{z})$ graphical analysis indicates the presence of two lines. One is oblique, showing proportionality between $\mathrm{F}(\mathrm{z})$ and $\mathrm{C}(\mathrm{z})$, and the other is horizontal, in the tree base, where there is no foliage.

\section{Results and discussion}

Above-soil total biomass data used in this study showed normality, according to the statistical tests. Bartlett's test indicated individual biomass homogeneity variance by $5 \mathrm{~m}$ section.

Diameter at breast height (dbh) and sampled trees mean total height were of $25.27 \mathrm{~cm}$ and $22.23 \mathrm{~m}$, respectively. It was also noticed that, for dbh variable, distribution median was of $24.04 \mathrm{~cm}$, and mode was of $21.96 \mathrm{~cm}$, indicating a slightly asymmetrical distribution. dbh minimum and maximum values were of 17.19 and $35.33 \mathrm{~cm}$. The total height variable had $23.12 \mathrm{~m}$ median and $23.10 \mathrm{~m}$ mode, indicating symmetrical distribution, with minimum and maximum distribution values of 12.80 and $27.50 \mathrm{~m}$, respectively (Table 1 ).

The individual biomass equation adjusted for ordinary linear regression was: $\ln (b)=-1.8860+$ $+2.2569 \ln (\mathrm{dbh})+0.8199 \ln (\mathrm{ht})$, with satisfactory adjustment degree, with $0.8694 \mathrm{R}^{2}{ }_{\text {aj. }}$ and $6.62 \% \mathrm{~S}_{\mathrm{yx}} \%$.

Table 1 - Breast height diameter and total height descriptive statistics of 20 Cryptomeria japonica trees planted in 1980, in Rio Negro municipality, Paraná state.

\begin{tabular}{lcccccc}
\hline Variable & Mean & Minimum & Maximum & Standard Deviation & CV $(\%)$ & $\mathrm{n}$ \\
\hline dbh $(\mathrm{cm})$ & 25.27 & 17.19 & 35.33 & 5.40 & 21.37 & 20 \\
Total height $(\mathrm{m})$ & 22.23 & 12.80 & 27.50 & 3.57 & 16.05 & 20 \\
\hline
\end{tabular}

The 20 samples above-soil mean individual dry biomass was of $283.41 \mathrm{~kg}$ per tree, with $208.78 \mathrm{~kg}$ in the stem compartment $(73.67 \%$ of the individual dry biomass), of which $118.06 \mathrm{~kg}$ corresponded to sapwood $(26.66 \%), 75.55 \mathrm{~kg}$ to the heartwood $(41.66 \%)$ and
$15.17 \mathrm{~kg}$ to the bark (5.35\%). Crown individual mean dry biomass was of $74.63 \mathrm{~kg}$ (i.e., with $26.33 \%$ individual dry biomass participation), with $35.66 \mathrm{~kg}$ of foliage $(12.58 \%)$ and $38.97 \mathrm{~kg}$ of branches (13.75\%) (Figure 1, Table 2).

Table 2 - Average above-soil biomass partitioning for 20 Cryptomeria japonica trees planted in 1984 in Rio Negro municipality, Paraná state.

\begin{tabular}{|c|c|c|c|c|}
\hline \multicolumn{5}{|c|}{ Stem dry biomass (kg) } \\
\hline Compartment & Mean & Standard Deviation & $\mathrm{CV}(\%)$ & $\mathrm{n}$ \\
\hline Sapwood & 118.06 & 63.17 & 53.51 & 20 \\
\hline Hearwood & 75.55 & 39.30 & 52.02 & 20 \\
\hline Bark & 15.17 & 2.54 & 16.74 & 20 \\
\hline Stem & 208.78 & 103.04 & 49.35 & 20 \\
\hline \multicolumn{5}{|c|}{ Crown dry biomass (kg) } \\
\hline Foliage & 35.66 & 62.87 & 176.30 & 20 \\
\hline Branches & 38.97 & 52.36 & 134.36 & 20 \\
\hline \multicolumn{5}{|c|}{ Total dry biomass $(\mathrm{kg})$} \\
\hline Total & 283.41 & 147.87 & 52.18 & 20 \\
\hline
\end{tabular}

Based on crown and stem biomass values, BEF values were calculated, which ranged from 1.21 to 1.58 , with mean of 1.37 and $8.32 \%$ coefficient of variation. BEF indicates stem biomass participation compared to the total above-soil biomass. It is customarily applied when there is tree volume 
information (usually obtained through its relation with $\mathrm{dbh}$ and total height), and shoot biomass estimation is needed. With wood density information (relating mass over volume), it is possible to estimate tree stem biomass. Then, BEF mean value is applied for tree stem biomass expansion to shoot biomass.

$\mathrm{BEF}$ is one of the most employed variables in forest biomass and carbon inventories (IPCC, 2003, 2006). Cheng et al. (2013), studying Cryptomeria japonica biomass carbon accumulation in Taiwan, found a value of 1.50 for trees with 30 years old. For this age group, trees analyzed by the authors were thinner and lower than those of the present study: approximately $20 \mathrm{~cm} \mathrm{dbh}$ and $18 \mathrm{~m}$ high. Lim et al. (2013) and Jung et al. (2014), while conducting related studies in South Korea, found values of 1.30 and 1.28 for the species in their studies, respectively.

Despite the large number of studies about the Japanese cedar wood, there are few studies highlighting differences between heartwood and sapwood (Yang et al., 1994; Carneiro et al., 2009; Pinto \& Iwakiri, 2013). Heartwood is the highest value portion in the timber market, as it has favorable characteristics in several applications, such as higher basic density and a higher resistance against fungal attack. As it is developed in cone form into the sapwood, the heartwood is often not found at the tree top (Yang et al., 1994), a fact reported in Pinus radiata (Wilkes, 1991) and Eucalyptus grandis (Wilkins, 1991). Due to heartwood characteristic formation, the tendency is of sapwood developing lower biomass per volume unit in relation to the heartwood. In this study, heartwood specific basic mean was of 0.40 , and sapwood was of $0.37 \mathrm{~g} \mathrm{~cm}^{-3}$, what, despite the small difference in density, as also depicted by Sanquetta et al. (2013), when multiplied by the respective volumes, resulted in a bit different and more inaccurate estimate than an average density for the whole wood, supporting the statement above. However, it is noted that in this study there was a higher biomass in the sapwood, considering that it represents higher volume compared to the heartwood, a fact explained by the higher volume amount proportionally than what is allocated at the heartwood compartment.

Regarding the mean vertical biomass partition, it was observed that in the first five meters high, biomass consists exclusively of wood, in which sapwood has the highest participation and bark the lowest percentage. In the tree base, heartwood participation in the wood fraction reaches about $40 \%$, decreasing with height, being $26 \%$ at the highest portion (between 20 and 25 $\mathrm{m})$. In the 5-10 $\mathrm{m}$ high stratum, the crown begins having a role in biomass, but in a lower percentage, with the wood providing a larger fraction, particularly sapwood. From then, crown participation grows, which is represented by branches and foliage. At $15 \mathrm{~m}$, these fractions become dominant, reducing stem participation (Figure 2).

Taking the adjusted equation and the forest inventory data carried out at 30 years of age as basis, it was estimated that the above-soil biomass per hectare in the stand in question is of $237.80 \mathrm{t} \mathrm{ha}^{-1}$. These values are comparable to pine and Araucaria stands, with close ages to those of this study, researched by Watzlawick (2003) in General Carneiro, PR. There are no comparable data for $C$. japonica in Brazil.

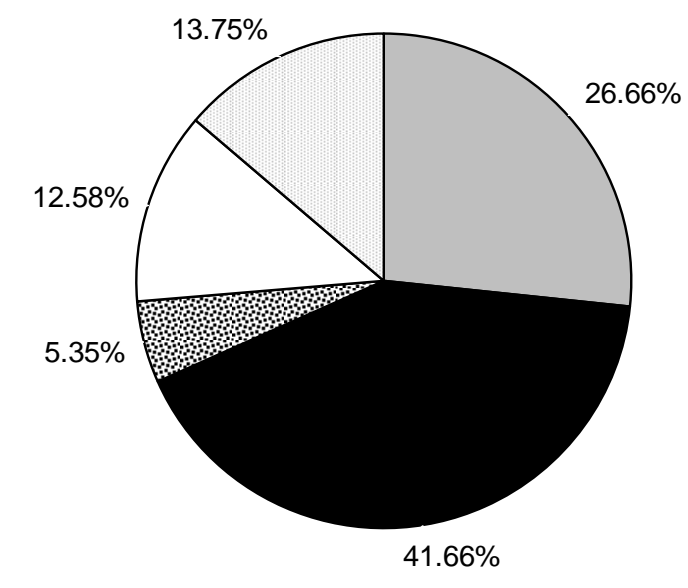

$\square$ Sapwood $\square$ Heartwood B Bark $\square$ Foliage $\square$ Branches

Figure 1 - Individual above-soil dry biomass partitioning per compartment in 20 Cryptomeria japonica trees planted in 1980 in Rio Negro municipality, Paraná state.

Regarding biomass mean vertical partition, for diameter classes of $<20 \mathrm{~cm}, 20-25 \mathrm{~cm}$ and $>25 \mathrm{~cm}$, it was observed that in the first five meters high biomass consisted exclusively of wood, in which sapwood has the majority participation, and bark appears in a lower percentage. At the tree base, heartwood participation in 
the fraction is higher (Figure 2a), decreasing with height towards the highest part (between 15 and $20 \mathrm{~m}$ ). In 5$-10 \mathrm{~m}$ high stratum, the crown begins to have a share in biomass, but to a lower extent, with wood providing a larger fraction, particularly the sapwood. From then, crown participation, which is represented by branches and foliage. The largest wood share can be seen in terms of biomass mean vertical partition in $20-25 \mathrm{~cm}$ and $>25 \mathrm{~cm}$ diameter classes, where up to $25 \mathrm{~m}$ in height represent much of this portion (Figure $2 b, c)$. It was noticed that, for the different diameter classes, biomass vertical distribution mean tendencies are similar, although changing such proportions magnitude.

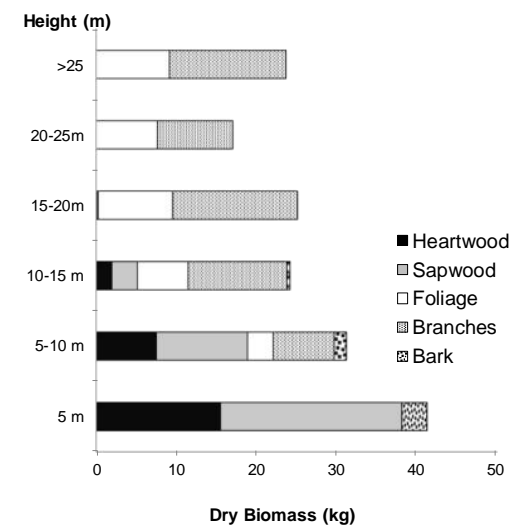

a) $<20 \mathrm{~cm}$ diameter class

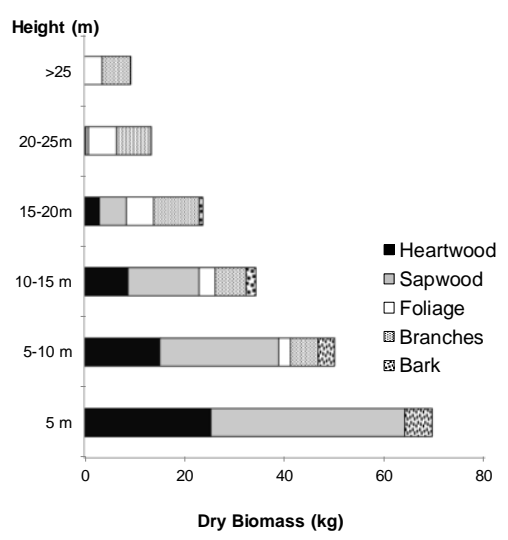

b) $20-25 \mathrm{~cm}$ diameter class

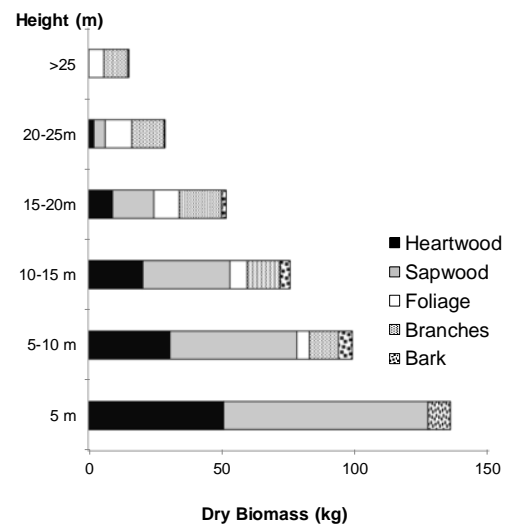

c) $>25 \mathrm{~cm}$ diameter class

Figure 2 - Individual above-soil dry biomass vertical partitioning in 20 Cryptomeria japonica trees planted in 1980 in Rio Negro municipality, Paraná state.

The relation between $C(z)$ and $F(z)$ for this study data suggest the existence of two lines, an oblique and a horizontal, pointing out that the Pipe Model Theory applies to the case (Figure 3). In this theory, there is a direct relation between each leaf biomass portion and the corresponding non-foliar portion, like interconnected pipes (Shinozaki et al., 1964). It is what is perceived by observing two lines (pipes) that are directly connected from $\mathrm{C}(\mathrm{z})$ and $\mathrm{F}(\mathrm{z})$ points adjustment. In other words, for each leaf tissue portion there is a corresponding stem portion. Authors also found that this relation is expressed by the oblique line on the tree top, which becomes the horizontal line on the bottom part, where there is no foliage. According to the authors, this due to heartwood formation, which consists of tissues that acquire the support function and lose the conduction function in the plant basal part, what is called "disused pipes", or pipes that are not used by the plant for sap conduction purposes.

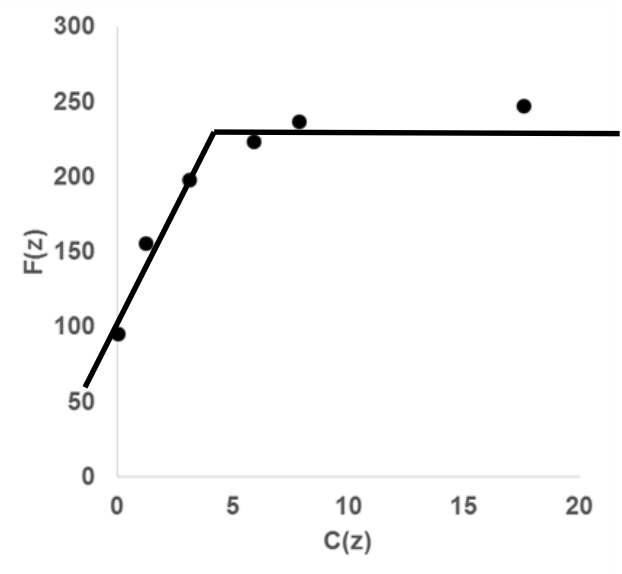

Figure 3 - Relation between biomass foliage $(C(z))$ and accumulated non-foliage biomass $(F(z))$ by horizontal stratum in 20 Cryptomeria japonica trees planted in 1980 in Rio Negro-PR.

\section{Conclusions}

Cryptomeria japonica major biomass fraction grown in pure stands condition is represented by the stem and, in this compartment, the sapwood corresponds the highest percentage;

In the tree first five meters, biomass consists exclusively of wood and bark. From $5 \mathrm{~m}$, crown biomass 
starts to have a share, coming out to be the largest fraction from the $15 \mathrm{~m}$ vertical profile;

There is a relation between foliage biomass and the stem and branches accumulated biomass, what indicates that the Pipe Model Theory applies to Cryptomeria japonica afforestation.

\section{References}

Alves ST, Shimizu JY, Higa AR, Higa RCV (1984) Teste de procedência de Cryptomeria japonica em três regiões do Estado do Paraná. Curitiba: Embrapa CNPF, 3p.

Capaldi FR (2002) Avaliação de diferentes fontes de nitrogênio em exemplares de Cryptomeria japonica D. Don. "elegans" cultivados in vitro: Análises bioquímicas e relações entre reguladores vegetais. USP (Master's dissertation on Forest Resources).

Carvalho DS (2011) Características da serapilheira e do solo sob florestas de coníferas e folhosas em Rio Negro, PR. UFPR (Master's dissertation on Soil Sciences).

Carneiro ME, Bittencourt E, Muniz G IB (2009) Qualidade da madeira de Cryptomeria japonica D. Don. Floresta 39( 4):913-920.

Cheng CH, Hung CY, Chen CP, Pei CW (2013) Biomass carbon accumulation in aging Japanese cedar plantations in Xitou, central Taiwan. Botanical Studies 54(60):1-9.

Chiba $Y(1998)$ Architectural analysis of relationship between biomass and basal area based on pipe model theory. Ecological Modelling 108: 219-225.

Dean TJ, Jerez M, Quang VC (2013) A simple stand growth model based on canopy dynamics and biomechanics. Forest Science 59(3):335-344.

Dobner Júnior MD, Trazzi PA, Higa AR, Arce JE (2013) Crescimento de um povoamento de Cryptomeria japonica no Sul do Brasil. Scientia Forestalis 41(97):39-46.

Gardner RH, Mankin JB (1981) Analysis of biomass allocation in forest ecosystems of the IBP. In: Reichle PD. Dynamic properties of forest ecosystems. Cambridge University Press. p.451-497.

Gillespie AR, Allen HL, Vose JM (1994) Amount and vertical distribution of foliage of young loblolly pine trees as affected by canopy position and silvicultural treatment. Canadian Journal of Forest Research 24:1337-1344.

IPCC - Intergovernmental Panel on Climate Change (2003) Good practice guidance for land use, land use change and forestry. Hayama, Japan. Available at: <http://www.ipcc-nggip.iges.or.jp>. (accessed mar 20 2015).
IPCC - Intergovernmental Panel on Climate Change (2006) Guidelines for national greenhouse gases inventories. Hayama, Japan. Available at: $<$ http://www.ipcc-

nggip.iges.or.jp/public/2006gl/index.html>. (accessed mar 20 2015).

Jelonek T, Pazdrowski W, Arasimowicz M, Tomczak A, Walkowiak R, Szaban J (2008) The applicability of the Pipe Model Theory in trees of Scots pine of Poland. Journal of Forest Science 54(11):519-531.

Jung SC, Lumbres RI, Won HK, Seo YO (2014) Allometric equations, stem density and biomass expansion factors for Cryptomeria japonica in Mount Halla, Jeju Island, Korea. Journal of Ecology and Environment 37(4):177-184.

Kindermann G, Obersteiner M, Sohngen B, Sathaye J, Andrasko K, Rametsteiner E, Schlamadinger B, Wunder S, Beach R (2008) Global cost estimates of reducing carbon emissions through avoided deforestation. PNAS 105(30):10302-10307.

Landsberg JJ, Sands P (2011) Physiological Ecology of Forest Production, Principles, Processes and Models. 1st edn. Academic Press, 352p.

Lim H, Lee K, Lee KH, Park IH (2013) Biomass expansion factors and allometric equations in an age sequence for Japanese cedar (Cryptomeria japonica) in southern Korea. Journal of Forest Research 18:316322.

Pereira JF (2009) Variação da umidade dos combustíveis florestais em função dos índices de perigo de incêndios FMA e FMA + em um povoamento de Pinus elliottii no município de Rio Negro, PR. UFPR (Master's dissertation on Forest Sciences).

Pinto JA, Iwakiri S (2013) Estudo sobre a viabilidade do uso da madeira de "Cryptomeria japonica" para produção de painéis compensado. Scientia Forestalis 41(97):29-37.

Poorter H, Niklas KJ, Reich PB, Oleskyn J, Poot P, Mommer $L$ (2012) Biomass allocation to leaves, stems and roots: meta-analyses of interspecific variation and environmental control. New Phytologist 193(1):30-50.

Sanquetta CR (2002) Métodos de determinação de biomassa florestal. In: Sanquetta, C. R. et al. (Eds.). As florestas e o carbono. p.119-140.

Sanquetta CR, Corte APD, Silva F (2011) Biomass expansion factor and root-to-shoot ratio for Pinus in Brazil. Carbon Balance and Management 6( 6):1-8.

Sanquetta MNI, Sanquetta CR, Corte APD, Mognon F, Mendonça VC (2013) Teores de carbono e densidade básica da madeira de Cryptomeria japonica (Thunb. ex L.f) D. Don. em povoamentos no município de Rio Negro- PR. Enciclopédia Biosfera 9(17):2450-2458. 
Sanquetta CR, Corte APD, Rodrigues AL, Watzlawick LF (2014) Inventários florestais: planejamento e execução, 3rd ed. 406p.

Shimizu JY, Maiochi RA (2007) Cryptoméria como espécie alternativa para produção de madeira no Paraná. Pesquisa Florestal Brasileira 54:63-70.

Shinozaki K, Yoda K, Hozumi K, Kira T (1964) A quantitative analysis of plant from: the pipe model theory. I. Basic analyses. Japanese Journal of Ecology 14:97-105.

Silveira P, Koehler HS, Sanquetta CR, Arce JE (2008) $O$ estado da arte na estimativa de biomassa e carbono em formações florestais. Floresta 38(1):185-206.

Telenius B, Verwijst T (1995). The influence of allometric variation, vertical biomass distribution and sampling procedure on biomass estimates in commercial short-rotation forests. Bioresource Technology 51(2-3):247-253.
Waring RH, Schroeder PE, Oren R (1982) Application of the pipe model theory to predict canopy leaf area. Canadian Journal of Forest Research 12(3):556-560.

Watzlawick LF (2003) Estimativa de biomassa e carbono em floresta ombrófila mista e plantações florestais a partir de dados de imagens do satélite IKONOS II. UFPR (PhD Thesis on Forest Science).

Wilkes J (1991) Heartwood development and its relationship to growth in Pinus radiata. Wood Science Technology 25:85-90.

Yang KC, Chen YS, Chiu C, Hazenberg G (1994) Formation and vertical distribution of sapwood and heartwood in Cryptomeria japonica D. Don. Trees $9: 35-40$.

Yen TM, Lee JS, Li CL, Chen YT (2013) Aboveground biomass and vertical distribution of crown for Taiwan red cypress 20 years after thinning. Dendrobiology 70:.109-116. 